\title{
PERSPECTIVE
}

\section{On Roald Amundsen's scientific achievements}

\author{
Arnoldus Schytte Blix \\ AAB Building, Institute of Arctic and Marine Biology, University of Tromsø, NO-9037 Tromsø, Norway
}

\section{Keywords}

Fridtjof Nansen; polar exploration; South Pole; North-west Passage; North-east Passage; H.U. Sverdrup.

\section{Correspondence}

Arnoldus Schytte Blix, AAB Building, Institute of Arctic and Marine Biology, University of Tromsø, NO-9037 Tromsø, Norway. E-mail: asb000@uit.no

\begin{abstract}
This paper describes the significant direct and indirect contributions to science made by the Norwegian polar explorer Roald Amundsen in the period 18971924. It documents that his expeditions through the North-west Passage (1903-06) with Gjøa, to the South Pole (1910-12) with Fram and through the North-east Passage (1918-1920) and the Chukchi and East Siberian seas (1921-25) with Maud yielded vast amounts of published scientific material on meteorology, terrestrial magnetism, geology, palaeontology, oceanography, ethnography, zoology and botany, which, though celebrated at the time, have since received scant recognition in more recent assessments of Amundsen's achievements.
\end{abstract}

To access the supplementary material for this article, please see the supplementary file under Article Tools, online.
There have been a number of biographies of Roald Amundsen (e.g., Holt 1974; Huntford 1979; BomannLarsen 1995; Kvam 1997) and during the centenary of his attainment of the South Pole in 1911 several new ones (e.g., Hansen 2011; Wisting 2011) were published in Norway. These books have not given proper notice to Amundsen's scientific achievements and some have questioned his importance as a scientist altogether. This paper argues that Amundsen contributed significantly to science, both directly and indirectly, and presents the scientific publications which emanated from his work.

\section{Preparations to become an explorer scientist}

As an eight- or nine-year-old boy Roald Amundsen came across the books about Sir John Franklin's expedition (Franklin 1823, 1828) and decided there and then to dedicate his life to polar research (Amundsen 1927). Moreover, in 1889 he was inspired by the hero's welcome given to Fridtjof Nansen after his crossing of Greenland. With the exception of a short detour as medical student, from then on he worked systematically and conscientiously to prepare himself for a career in polar research. First he learnt to ski during a series of long and trying trips in mountainous Norway and thereafter, like the young Nansen, he joined a sealing expedition to the Greenland Sea. After this he became a sailor in the merchant marine and received his international first mate's certificate.

With this in his pocket he was hired as first mate aboard Belgica, which sailed from Antwerp to Antarctica on 16 August 1897 and made the first wintering ever in the pack ice south of the southern polar circle (Decleir 1998). Under poor leadership, the expedition members suffered from scurvy and depression, which taught Amundsen much about how things should not be done. That winter he conceived the idea of locating the position of the North Magnetic Pole. James Clark Ross had already reached its approximate location in 1831 (Ross 1834) but a hotly debated question at that time was whether it had a permanent location or migrated.

During his tenure as first mate in the merchant marine Amundsen happened to come to Grimsby in England where he came across a complete library on the Northwest Passage, which he studied extensively. Thereafter he travelled to Hamburg to learn about terrestrial magnetism from Georg von Neumayer. Just before Christmas 1900 he presented his plan to a very enthusiastic Fridtjof Nansen, and then he went to Tromsø in northern Norway and bought the sealing schooner Gjøa. He then sailed as 
skipper on his own deck on a six-month sealing expedition in the Greenland and Barents seas to practice ice navigation. He also collected vast amounts of oceanographic data that were subsequently published by Nansen (Nansen 1906). In November 1901 he officially presented his plan to the Norwegian Geographical Society (Amundsen 1901).

\section{The North-west Passage}

From here on he employed his usual vigour to acquire the very best available instruments and went about learning to use them with great enthusiasm. He made extensive field trials with Professor Aksel Steen, meteorologist and leading authority on terrestrial magnetism in Norway at the time, and went to the magnetic observatory in Potsdam to learn the practicalities of magnetic observation. He was also lucky to meet the now famous Otto Sverdrup, who had just returned from his expedition to the Canadian High Arctic (Sverdrup 1903), from whom he learnt about the use of dogs in the Arctic. Then he toured Britain to meet survivors of the Franklin search expeditions to acquire local knowledge about the conditions in the North-west Passage. He also returned several times to Potsdam to continue his studies and received his international certificate as captain in the merchant marine, all in the course of two years.

Amundsen left Christiania (Oslo) aboard Gjøa, with seven men, on 17 June 1903 and after a sometimes dramatic voyage arrived at King William Island (Supplementary Fig. S1), near the assumed location of the North Magnetic Pole, on 9 September 1903. He dropped anchor in what was later named Gjøahavn (now Gjoa Haven; Amundsen 1903-05). With the ship frozen in, they built a magnetometer laboratory and an astronomical observatory ashore. For 19 months they performed a series of measurements, with no less than 10 complicated and delicate instruments, of the direction, strength and variation of the magnetic field (Egeland \& Deehr 2011) and made meteorological observations three times every day. They made two abortive attempts to reach the North Magnetic Pole during which they experienced day temperatures of $-53^{\circ} \mathrm{C}$ and night temperatures as low as $-61.7^{\circ} \mathrm{C}$. Finally Amundsen and Ristvedt embarked on a 51-day journey with dog teams and skis, now with ambient temperatures averaging $-30^{\circ} \mathrm{C}$ (Ristvedt 1942), and located the North Magnetic Pole at $70^{\circ} 30^{\prime} \mathrm{N}, 95^{\circ} 30^{\prime} \mathrm{W}$. They proved that it is not stationary and that its position moves in a steady manner.

Next spring Godfred Hansen and Ristvedt travelled $1450 \mathrm{~km}$ in 86 days, using dog teams and skis, and made extensive topographic surveys of King William Island and the-until then-unknown east coast of Victoria Land, which was named Haakon VIIs Coast, after the new King of Norway (Hansen 1907).

Besides this Roald Amundsen was an ardent student of the local Netsilik Inuit. He made detailed ethnographical studies of the Netsilik, who were probably the last Arctic people not to have made contact with Europeans. He collected some 900 items of clothing and tools (Taylor 1974) which are now deposited in the Ethnographical Museum in Oslo (Arnesen 1942). Amundsen also wrote a 70-page dissertation on the behaviour and techniques of the Netsilik in the original edition of his account of the expedition (Amundsen 1907a). Furthermore, Lindstrøm, the cook (Ekeberg 2000), collected vast amounts of zoological and botanical material for Professor Collett and others at the University of Christiania (see Supplementary File) while Helmer Hanssen was continually hunting for fresh meat, sometimes with the help of Ristvedt (1933).

On 13 August 1905 Gjøa escaped from the ice and sailed farther through the North-west Passage. On 17 August they reached Cape Colbourne, the easternmost point that had been reached by any ship coming from the Bering Strait, by which the North-west Passage had been navigated in full for the first time. Gjøa was again stopped by the pack ice at King Point near the border between the Yukon and Alaska (Supplementary Fig. S1), where they spent a third winter. That winter they continued their magnetic and meteorological observations, which at that time had been more or less taken over by Wiik, Amundsen's assistant, until he became ill and died in the spring of 1906. During that winter Amundsen put on his skis and went $2600-\mathrm{km}$ round trip by dog team via Herschel Island and Fort Yukon, with ambient temperatures between -30 and $-50^{\circ} \mathrm{C}$, to Eagle City, Alaska, where there was a telegraph station, to tell the world about his conquest. Finally, on 10 August Gjøa got free from the grip of the ice and reached Nome, Alaska, on 31 August 1906.

The amount of research the seven men aboard Gjøa managed to do under extreme conditions is astounding: The internationally published results in geophysics, biology, geology and palaeontology comprise no fewer than 600 printed pages, plus an abundance of appendices (see Supplementary File) Additionally, a book on Netsilik culture (Amundsen 1907a), the map of King William Land published by the Norwegian National Mapping Authority, 300 photographs of great and lasting historical and cultural value were made (e.g., Eek 1998) and the above-mentioned unique collection of Netsilik artefacts collected and preserved for future examination (Taylor 1974).

Shortly after his return to Norway Roald Amundsen was elected a member of the Norwegian Academy of Science and Letters, the equivalent of the Royal Society 
and the British Academy, combined, on 22 March 1907 and, in the same year, he received from the academy the Nansen Prize, at that time the most prestigious Norwegian prize, "for his outstanding research regarding the magnetic conditions around the North Magnetic Pole and for his discovery of the North-west Passage" (Brøgger 1921: 168; my translation).

While it is arguable that the Norwegian celebration of Amundsen's scientific achievements was a gross overstatement arising from the nation-building of which Nansen was a key driver, a careful consideration of the scientific output of Amundsen's expedition shows that his contributions to science were, in fact, considerable and, for the time, represented state of the art science. It is worth noting that when Amundsen delivered his lecture on the Gjøa expedition to the Royal Geographical Society in London, on 11 February 1907, British admirals and other notables were queuing to praise his achievements, not so much for his discovery of the North-west Passage as for his groundbreaking studies of magnetism around the North Magnetic Pole (Amundsen 1907b). Today his work on magnetism is met with admiration among his peers (Egeland \& Deehr 2011).

\section{The South Pole}

On 29 April 1907 Nansen delivered a seminal lecture to the Royal Geographical Society in London about the future challenges for polar research and emphasized that investigation of the Arctic Ocean should have first priority (Nansen 1907). Roald Amundsen immediately rose to the bait and asked Nansen for permission to use Fram, which, after some hesitation was granted, and on 10 November 1908 he presented his plan for the expedition to the Norwegian Geographical Society (Amundsen 1909). The plan was received with great acclaim at the meeting by both Mohn, the great Norwegian meteorologist who first suggested the existence of a trans-polar drift (Mohn 1885), and Nansen. True to habit, Amundsen proceeded to study oceanography with Helland-Hansen, who became his friend and confidant, in Bergen.

However, on l September 1909 Fredrick Cook, whom Amundsen had known on the Belgica expedition, declared that he had reached the North Pole on 21 April 1908. One week later Peary claimed to have been there on 6 April 1909. Amundsen immediately understood that the bottom had dropped out of his chance to finance a costly expedition to the North Pole and he jumped at a change of plan: he would be the first to reach the South Pole.

It is well known that he sailed south aboard Fram filled with dogs on an-as usual-grossly under-financed expedition and when the change of plan was revealed to his crew at Madeira all hands were in enthusiastic support. They reached the Bay of Whales in the Ross Sea on 13 January 1911, establishing Framheim, their winter station, $1500 \mathrm{~km}$ from the South Pole (Amundsen 1912).

It seems generally accepted that the Norwegian expedition, unlike the British one under Scott, was an unscientific race with the one and only aim of being first at the South Pole. However, the fact remains that Amundsen's expedition spent over a month collecting oceanographic data for Nansen from 25 stations around the British Isles before going south and, while the Land Party was in Antarctica, Fram was used to collect original oceanographic data between South America and South Africa under the leadership of the Russian Alex Kutschin (Schröer et al. 2011), over a distance of 8000 nautical miles, making 60 stations, collecting 891 water samples and 190 plankton samples (Gjertsen 2011 ; Nilsen 2011). The results of this investigation were published in Norwegian and English by Helland-Hansen $\&$ Nansen (1912) shortly afterwards. Moreover, Amundsen in person made meteorological observations of pressure, temperature, humidity, wind, cloud cover, cloud classification, precipitation, aurora and sun halo three times a day throughout his entire stay at Framheim, and he even made a series of observations during the traverse to the South Pole. All this was later published by Mohn $(1915,1916)$. The Polar Party surveyed a pristine approach to the South Pole through what Amundsen named Queen Maud Mountains, where geological samples were collected and, not least, proved that the Ross Sea was not connected to the Weddell Sea. His East Party, under the command of Lieutenant Prestrud, was the first to set foot on King Edward VII's Land, where geological samples again were collected. These results were published in English by Schetelig (1915).

Amundsen and his four companions reached the South Pole on 14 December 1911 and on his return, after having received the highest honours of the Norwegian nation, Amundsen revived his research group leader function and gave an exhausting series of lectures in Britain and the US in 1912 and 1913 to raise money for the North Pole expedition he had originally planned. He gave a most colourful and humorous account of the horrors he went through on those occasions in the introduction to his book The North-east Passage (Amundsen 1921).

\section{The North-east Passage}

When Fram, after a prolonged delay in Central America eventually made it back to Norway on 16 July 1914 it was clear that the ship had deteriorated beyond repair 
and, for good measure, the Great War broke out soon after and halted further planning of the new expedition. However, Amundsen seized the opportunity and speculated in shipping stocks. For once in his life he bagged no less than 100000 pounds (1916 value), which at that time was sufficient to eliminate all his debts and pay for a new ship, named Maud, that was purpose-built for the North Pole expedition.

A number of what we would today have called international workshops were organized for the planning of the scientific programme, and the proceedings published (Hesselberg 1920; Krogness 1920; Norwegian Geophysical Commission 1920). The original plan had been to approach the Pole from the Bering Strait, but, probably because of the wartime situation, the new plan was to do like Nansen (Nansen 1897) and approach it from the North-east Passage.

Maud left Oslo on 24 June and Vardø (close to the Russian border) on 18 July 1918 but was stopped by pack ice close to Cape Cheluskin, where they established Maudheim, their first winter station, on 18 September (Supplementary Fig. S2). This time Amundsen had brought with him his new precious discovery, the later famous oceanographer, Harald U. Sverdrup (e.g., Devik 1959), as scientific leader. Amundsen himself was now director of the expedition while his old chum from the North-west Passage and the South Pole, Helmer Hanssen, found himself in the dubious position of having been named captain of the ship. As previously, when they landed they commenced astronomical, meteorological and magnetic observations, they collected geological samples, made tidal measurements and took numerous photographs (Amundsen 1921).

They escaped the grip of the ice on 11 September 1919 but were stuck in the ice again off Ayon Island, outside the mouth of Kolyma River (Supplementary Fig. S2) a couple of weeks later and had to prepare for a second winter without coming into contact with the trans-polar drift that was supposed to carry them to the North Pole. As before, they continued their series of recordings while Sverdrup embarked on a six-month journey with skis and a dog team throughout Chukotka in eastern Siberia to make anthropological studies of the Chukchi people, from whom he collected a great many artefacts and about whom he published a book (Sverdrup 1921). Just before Christmas, Helmer Hanssen and Oscar Wisting were dispatched with dog teams on an amazing journey via Cape Dezhnev (East Cape) on the Bering Strait to Anadyr, where there was a telegraph station, to communicate with the outside world. This journey, which lasted no less than 195 days and covered $4000 \mathrm{~km}$, is described by Hanssen (1921, 1941).
On 8 July they became free again and reached Nome on 27 July 1920, having traversed the North-east Passage.

Maud left Nome after only a couple of weeks, in August 1920, and sailed north in another attempt to enter the trans-polar drift. They were met with extreme ice conditions and became stuck just north of the Bering Strait. While Amundsen and Olonkin looked after the ship, Sverdrup, who was by then fluent in Chukchi, with Wisting embarked on an ethnographical odyssey with dog teams on the Chukchi Peninsula, which Sverdrup described in two books (Sverdrup 1926, 1938).

Having been repaired in Seattle, Maud went north again, with Wisting as captain (Wisting 1930, 1937), entering the pack ice east of Wrangel Island on 8 August 1922. During the next spring they started to fly reconnaissance flights in the Curtis plane that Amundsen had acquired for the expedition, with Odd Dahl as pilot and Wisting as observer (Dahl 1981). Unfortunately, they crashed spectacularly and terminally after only a few attempts. Still, they were the first to take off and land on ice in the Arctic Ocean and this began a new era in polar research. Maud eventually reached an unknown area (Supplementary Fig. S3) and was in fact a drifting laboratory (Fig. 1), where all scientific routines, as always, went as normal, even at $-40^{\circ} \mathrm{C}$. This continued for more than two years until 17 February 1924, when they received a telegram from Amundsen ordering them to return to San Francisco post haste because of economic collapse.

The expedition resulted in five books (Amundsen 1921; Hanssen 1921; Sverdrup 1921, 1926, 1938), 2000 internationally published pages of science with 40 appendices in five major volumes and 25 separate scientific articles on geophysics and oceanography (see Supplementary File).

I close this part of the paper at the conclusion of the Maud expedition, a few years before Amundsen's demise because it represents the conclusion of his scientific career if one discounts his geographical discoveries during the trans-polar flight aboard the airship Norge (Amundsen 8 Ellsworth 1926; Skattum 1929).

\section{Was Roald Amundsen a scientist?}

After a short stint as a medical student at the University of Christiania, Amundsen dropped out of academia and dedicated himself entirely to the study of the practicalities of measuring terrestrial magnetism, and in that field he unquestionably became an international authority. After the Gjøa expedition, however, it is quite clear that he began to change from a hands-on scientist to research group leader for whom finance, strategic thinking and expedition planning were steadily taking up more and more of his time. It is also quite likely that Amundsen's 


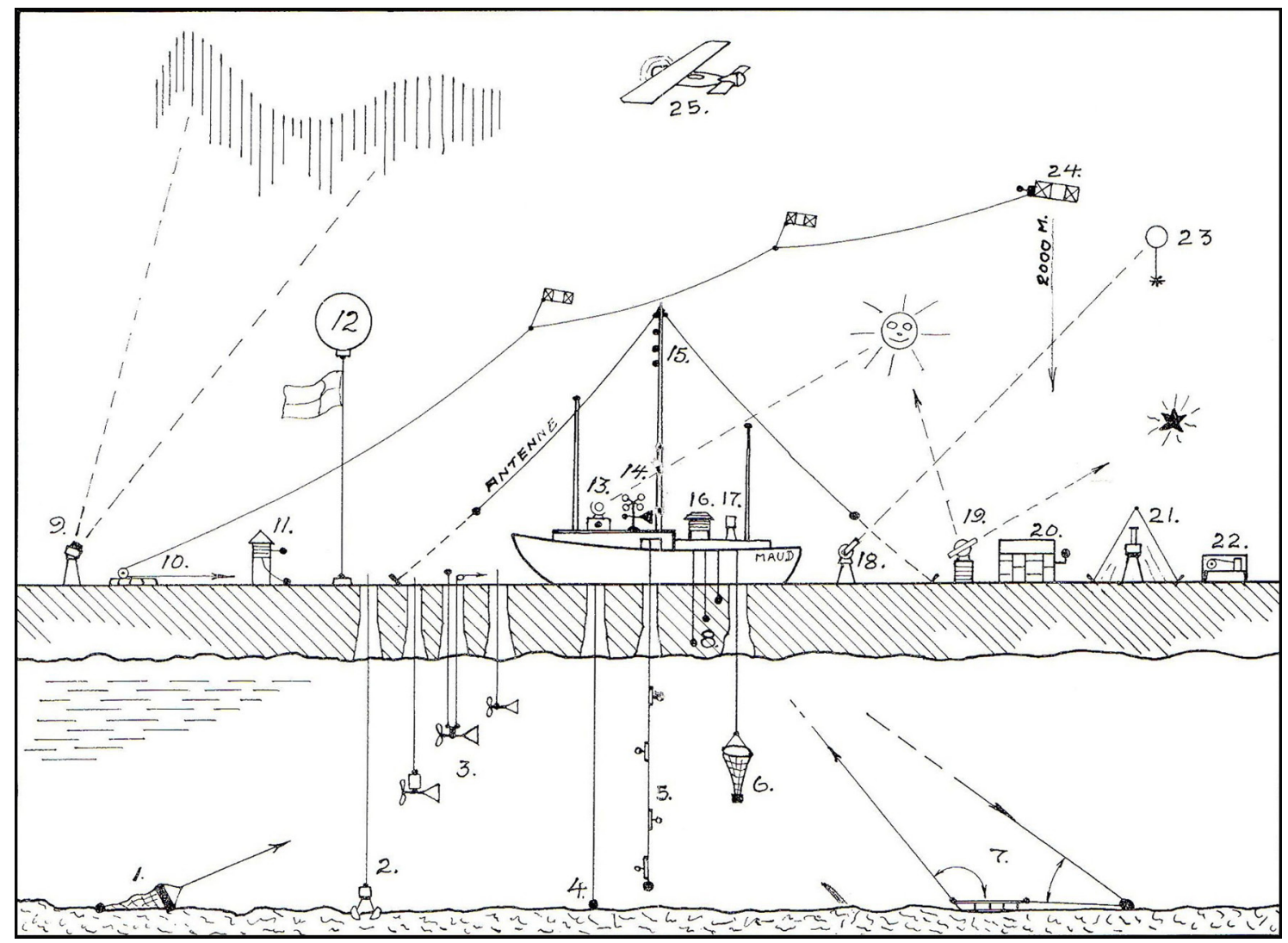

Fig. 1 Sketch of the instrumentation onboard the floating laboratory Maud, as drawn by pilot, instrument-maker and handyman, Odd Dahl: (1) bottom scraper; (2) bottom sampler; (3) current meter; (4) depth gauge; (5) water sampler; (6) plankton net; (7) tide gauge; (8) electrical thermometers; (9) aurora camera; (10) and (24) kites for high-altitude meteorological measurements; (11) heat flux from ice gauges; (12) balloon for collecting meteorological data; (13) solar activity and electrical activity; (14) direction and strength of wind; (15) electrical thermometers; (16) meteorological station; (17) precipitation; (18) and (23) balloon for observing wind direction at high altitude; (19) astronomical positioning; (20) air electrical measurements; (21) magnetic recordings; (22) continuous recording of variation of magnetic declination; (25) reconnaissance plane (illustration from Dahl \& Lunde 1976).

reputation as a scientist has been influenced by the fact that he never let himself appear as an (co-)author of any of the very many publications from his research group. We can only speculate what his status would have been today had he done so. One factor that quite certainly contributed to his lack of status as a scientist was that Nansen, in his otherwise very flattering eulogy (Nansen 1929: 145), stated that "Scientist Amundsen was not" (in the original: "Videnskapsmann var Amundsen ikke"). However, this much used quotation begs explanation. In Norwegian there are two different terms for scientist, each with a different meaning. We have videnskapsmann, who is a person who seeks to discover and elucidate the fundamental principles of the natural world-Einstein, Watson and Crick are outstanding examples - and we have forsker, being all the rest, that is, those who make important contributions in collecting and describing data that are made available to the former to build new models and understanding. Nansen used the Norwegian term videnskapsmann, which Amundsen quite rightly was not, which is not to say that he was not a scientist in the sense of forsker, which he certainly was.

\section{References}

Amundsen R. 1901. En paatænkt undersøkelsesreise til den magnetiske Nordpol. (A plan for an expedition to the North Magnetic Pole.) Det Norske Geografiske Selskabs Aarbog 12(1900-01), 167-176.

Amundsen R. 1903-05. Diaries from the Gjøa expedition. Oslo: Manuscript Department, National Library of Norway.

Amundsen R. 1907a. Nordvestpassagen. Christiania (Oslo): Aschehoug. Published in English in 1908 as The Northwest Passage. Vols. 1-2. London: Archibald Constable.

Amundsen R. 1907b. To the North Magnetic Pole and through the North-west Passage. The Geographical Journal 29, 485-513. 
Amundsen R. 1909. Plan for en polarfærd 1910-1917. (Plan for a polar expedition, 1910-17.) Det Norske Geografiske Selskabs Aarbog 20(1908-09), 55-75.

Amundsen R. 1912. Sydpolen. Bind 1-2. Christiania (Oslo): Jacob Dybwads Forlag. Published in English in 1912 as The South Pole. Vols. 1-2. London: John Murray.

Amundsen R. 1921. Nordostpassagen. (The North-east Passage.) Christiania (Oslo): Gyldendal.

Amundsen R. 1927. Mitt liv som polarforsker. Oslo: Gyldendal. Published in English in 1928 as My life as an explorer. New York: Doubleday.

Amundsen R. \& Ellsworth L. 1926. Den første flugt over Polhavet. Oslo: Gyldendal. Published in English in 1928 as The first flight across the Polar Sea. London: Hutchinson \& Co.

Arnesen O. 1942. Roald Amundsens innsats som etnograf. (Roald Amundsen's achievements as ethnographer.) Polarårboken 1942, 91-98.

Bomann-Larsen T. 1995. Roald Amundsen. Oslo: Cappelen. Published in English in 2006 as Roald Amundsen. Stroud: Sutton Publishing.

Brøgger W.C. 1921. Fridtjof Nansens Fond og de dermed forbundne fond til videnskapens fremme 1896-1921. (Fridtjof Nansen's Fund and the related funds to promote the progress of science 1896-1921.) Christiania (Oslo): A.W. Brøggers Boktrykkeri.

Dahl O. 1981. Trollmann og rundbrenner. (Wizard and maverick.) Oslo: Gyldendal.

Dahl O. \& Lunde R. 1976. Odd Dahl og Maudferden. (Odd Dahl and the Maud expedition.) Oslo: Christian Schibsteds Forlag.

Decleir H. (ed.) 1998. Roald Amundsen's Belgica diary. Antwerp: Hadewijch.

Devik O. 1959. Minnetale over Professor Harald U. Sverdrup. (Obituary for Professor Harald U. Sverdrup.) Årbok Det Norske Videnskabs-Akademi i Oslo 1958, 49-73.

Eek A.C. 1998. The Roald Amundsen photographs of the Netsilik people, 1903-05. In J.C.H. King \& H. Lidchi (eds.): Imaging the Arctic. Pp. 106-116. Seattle, WA: University of Washington Press.

Egeland A. \& Deehr C.S. 2011. Roald Amundsen's contributions to our knowledge of the magnetic fields of the Earth and the Sun. History of Geo- and Space Sciences 1, 1-14.

Ekeberg J.O. 2000. Et liv $i$ isen. (A life in the ice.) Oslo: Kagge Forlag.

Franklin J. 1823. Narrative of a journey to the shores of the Polar Sea. London: John Murray.

Franklin J. 1828. Narrative of a second expedition to the shores of the Polar Sea. London: John Murray.

Gjertsen H.F. 2011. Dagbok fra Sydpolsekspedisjonen, 1910-12. (Dairy from the South Pole expedition. 1910-12.) Oslo: Fram Museum.

Hansen G. 1907. Mod Kong Haakon VII's Land. (Towards King Haakon VII's Land.) In R. Amundsen (ed.): Nordvestpassagen. (The North-west Passage.) Pp. 455-507. Christiania (Oslo): Aschehoug.

Hansen J.I. 2011. Amundsens betrodde mann. (Amundsen's confidant.) Oslo: Schibsted.

Hanssen H. 1921. Et halvt aars slædetur for at faa sendt et telegram. (A six-month sledging journey to send a telegram.)
In R. Amundsen (ed.): Nordostpassagen. (The North-east Passage.) Pp. 398-420. Christiania (Oslo): Gyldendal.

Hanssen H. 1941. Gjennem isbaksen. Oslo: Aschehoug \& Co. Published in English in 1936 as Voyages of a modern Viking. London: George Routledge \& Sons.

Helland-Hansen B. \& Nansen F. 1912. De oceanografiske undersøkelser gjort med "Fram" i Nord-Atlanteren i 1910 og i Syd-Atlanteren 1911. (Oceanographic investigations with Fram in the North Atlantic in 1910 and in the South Atlantic in 1911.) In R. Amundsen (ed.): Sydpolen. (The South Pole.) Vol. 2. Pp. 362-403. Christiania (Oslo): Jacob Dybwads Forlag.

Hesselberg T. 1920. On the projected co-operation with Roald Amundsen's North Polar Expedition. Geofysiske Publikasjoner 1(4), 1-4.

Holt K. 1974. Kappløpet. Oslo: Gyldendal. Published in English in 1976 as The Race. London: Michael Joseph.

Huntford R. 1979. Scott and Amundsen. London: Hodder and Stoughton.

Kvam R. 1997. Den tredje mann. (The third man.) Oslo: Gyldendal.

Krogness O. 1920. The importance of obtaining magnetic registrations from a comparatively close net of stations in the polar regions. Geofysiske Publikasjoner 1(4), 8-18.

Mohn H. 1885. Meddelelse om fund af levninger fra Jeannetteexpeditionen. (A report on the finding of remains from the Jeannette expedition.) Forhandlinger $i$ Videnskabs-Selskabet i Christiania 1884, 14-15.

Mohn H. 1915. Meteorology. Roald Amundsen's Antarctic expedition. Scientific results. Videnskapsselskapets Skrifter 1, MatematiskNaturvidenskabelig Klasse 5. Christiania (Oslo): Jacob Dybwad.

Mohn H. 1916. Der Luftdruck zu Framheim und seine tägliche Periode. (Air pressure at Framheim and its daily changes.) Roald Amundsens Antarktische expedition. Wissenschaftliche ergebnisse. Videnskapsselskapets Skrifter 1, Matematisk-Naturvidenskabelig Klasse 3. Christiania (Oslo): Jacob Dybwad.

Nansen F. 1897. Fram over Polhavet. Bind 1-2. Christiania (Oslo): Aschehoug. Published in English in 1897 as Farthest north. Vols. 1-2. London: Constable.

Nansen F. 1906. Northern waters: Captain Roald Amundsen's oceanographic observations in the Arctic seas in 1901 with a discussion of the origin of the bottom-waters of the northern seas. Videnskabs-Selskabets Skrifter 1. Mathematisk-Naturvidenskabelig Klasse 3. Christiania (Oslo): Jacob Dybwad.

Nansen F. 1907. On North Polar problems. The Geographical Journal 30, 469-487.

Nansen F. 1929. Roald Amundsen. Norsk Geografisk Tidsskrift 2, $141-146$.

Nilsen T. 2011. Dagbok fra Sydpolsekspedisjonen 1910-12. (Dairy from the South Pole expedition 1910-12.) Oslo: Fram Museum.

Norwegian Geophysical Commission 1920. Geophysical investigations in the Arctic regions in co-operation with Roald Amundsen's expedition. Geofysiske Publikasjoner 1(4), 5-7.

Ristvedt P. 1933. Jaktoplevelser i Nordvestpassasjen. (Hunting adventures in the North-west Passage.) Polararboken 1933, $41-51$.

Ristvedt P. 1942. Med Roald Amundsen på sledetur til den magnetiske nordpol. (With Roald Amundsen on a sledging journey to the North Magnetic Pole.) Polararboken 1942, 99-102. 
Ross J.C. 1834. On the position of the North Magnetic Pole. Philosophical Transactions of the Royal Society of London 124, 47-51.

Schetelig J. 1915. Report on rock-specimens collected on Roald Amundsen's South Pole expedition. Roald Amundsen's Antarctic expedition. Scientific results. Videnskapsselskapets Skrifter I, Matematisk-Naturvidenskabelig Klasse 4. Christiania (Oslo): Jacob Dybwad.

Schröer A., Hansen L., Rønne M., Kutschin A., Wisting O., Hanssen H., Stubberud J. \& Doxrud C. 2011. Dagbøker fra Sydpolsekspedisjonen, 1910-12. (Diaries from the South Pole expedition, 1910-12.) Oslo: Fram Museum.

Skattum O.J. 1929. Roald Amundsen som geografisk opdager. (Roald Amundsen as explorer.) Norsk Geografisk Tidsskrift 2, 147-175.

Sverdrup H.U. 1921. Blant Rentsjuktsjere og Lamuter. (Among the reindeer Chukchi and the Lamut.) In R. Amundsen (ed.): Nordostpassagen. (The North-east Passage.) Pp. 257-391. Christiania (Oslo): Gyldendal.
Sverdrup H.U. 1926. Tre aar i isen med "Maud." (Three years in the ice with Maud.) Oslo: Gyldendal.

Sverdrup H.U. 1938. Hos tundra-folket. Oslo: Gyldendal. Published in English in 1978 as Among the tundra people. San Diego: University of California Press.

Sverdrup O. 1903. Nyt land. Fire år $i$ arktiske egne. Bind 1-2. Christiania (Oslo): Aschehoug. Published in English in 1904 as New land: four years in Arctic regions. Vols. 1-2. London: Longmans, Green \& Co.

Taylor J.G. 1974. Netsilik Eskimo material culture. The Roald Amundsen collection from King William Island. Oslo: Universitetsforlaget.

Wisting A. 2011. Roald Amundsen. Oslo: Kagge Forlag.

Wisting O. 1930. Seksten ar med Roald Amundsen. (Sixteen years with Roald Amundsen.) Oslo: Gyldendal.

Wisting O. 1937. Roald Amundsen. Norsk Geografisk Tidsskrift 6, 233-234. 